continuous tone-series," which are almost as familiar as "Politzer's method" of inflation. The continuous tone-series led to investigations which have entitled Professor Bezold to a place among the great benefactors of the human race, namely, his indefatigable examination into the residuum of hearing-power present in "deafmutes." Owing to this line of study many have learned to converse with their fellows by the ordinary means of communication instead of being condemned to the use of signs and finger-alphabets. His "Text-book of Otology," issued so recently as 1906, and translated into English by Holinger in 1908, contains, in very moderate space, the outcome of his long investigations in relation to the diagnosis and treatment of diseases of the ear.

Professor Bezold was obviously of a nervous temperament, and it is recorded of him that he was so diffident as to his capacity for teaching that he hesitated long before deciding to seek appointment as an instructor in the University. He lost his father when very young, and was therefore brought up and mainly educated by his mother, with the not unusual results of such training. 'Thus we find an almost pathological amount of industry as the expression of a morbidly conscientious desire to counteract such mediocrity as that with which he credited himself. His work, though no doubt a labour of love, was nevertheless withont doubt a labour, and the earnest expression of his features could not fail to convey to the observer the strain under which his enormous work was carried on. The world owes a great deal to the owners of the nervous temperament, and the otologist's indebtedness to Professor Bezold is indeed enormous.

Sympathetic and comprehensive obituary notices of the illustrious deceased are to be found in the Deutsche medizinische Wochenschrift, December 24, 1908 (No. 52), and the Münchener medizinische Wochenschrift, November 3, 1908 (No. 44), by the well-known aurists, his distinguished pupils, Professor Scheibe, of Munich, and Professor Denker, of Erlangen, respectively.

\title{
BAUER'S METHOD OF SEROLOGICAL DIAGNOSIS OF SYPHILIS.
}

In view of the questions with regard to Bauer's method of serological diagnosis raised in the discussion on syphilis especially affecting the upper air-passages in the Laryngological Section of the Royal Society of Medicine, the following translation of the description of this method, as given by the author in No. 16 of the 
Deutsche medizinische Wochenschrift for 1908, will probably be read with considerable interest. Without entering into theoretical considerations, the following is an exact statement of the method employed, which is a simplification of the original Wassermann method.

If normal human serum mixed with the serum of the guinea-pig is added to sheep's blood, hæmolysis of the latter takes place pretty rapidly, and if, instead of normal human serum, syphilitic serum is employed, the hæmolysis is much retarded. If, further, to the two sera some liver-extract (as prepared by Michaelis and Lesser) is added the hæmolysis is absent, while if normal instead of syphilitic is used complete hæmolysis takes place. The liver-extract is made as follows: The liver of a syphilitic fœetus or infant is rubbed down and shaken over-night in ten times its bulk of absolute alcohol. The supernatant fluid produced by centrifuging is, when used, mixed with four times its bulk of normal saline solution. It is then tested as to whether 1 c.c. prevents the hæmolysis of 1 c.c. of sheep's blood with $0 \cdot 2$ c.c. of normal human serum and $0 \cdot 1$ c.c. of guinea-pig serum. If it does, it is diluted till the strength is reached which. no longer prevents hæmolysis.

The following are the materials required for testing for syphilis in a given case: (1) Guinea-pig serum, which must be fresh or preserved by freezing; (2) liver extract as above described; (3) a 5 per cent. suspension of sheep's blood-corpuscles in normal saline solution; (4) serum from the patient heated to $56^{\circ} \mathrm{C}$. $\left(132.8^{\circ} \mathrm{F}\right.$.) in a water-bath for half an hour; (5) the same from a healthy subject similarly heated.

Four test-tubes are then employed. In the first is poured 0.2 c.c. of the patient's serum, 1 c.c. of the liver extract, and 1 c.c. of a 1 in 10 dilution of guinea-pig serum. The second holds the same, but with normal saline solution instead of liver extract. In the third is put 0.2 c.c. of healthy human serum with liver extract and guinea-pig serum as in the first. The fourth is similar to the third, but with normal saline instead of liver extract. The four tubes are left in an incubator or water-bath at $37^{\circ} \mathrm{C}$. $\left(98 \cdot 6^{\circ} \mathrm{F}\right.$.) for half an hour, and then 1 c.c. of the suspension of sheep's corpuscles above described is added to each. After from fifteen to forty-five minutes hæmolysis takes place in the third and fourth tubes, and at the same time or sooner or later in the second, but if the patient's serum is syphilitic the first tube shows no hæmolysis.

D. G. 